\title{
NO DISABILITY STANDPOINT HERE!: LAW SCHOOL FACULTIES AND THE INVISIBILITY PROBLEM
}

\author{
Leslie Pickering Francis and Anita Silvers*
}

Endeavors to increase diversity in higher education invite many questions, including concerns about consistent and categorical application of the motivating values. For example, do law schools, and especially elite law schools, do enough to promote inclusiveness in the legal profession if their efforts are limited to admitting students from underrepresented minorities and not equally striving for similar diversity among the faculty? Where the students are diverse but the teachers are not, inclusiveness does not seem to rise to the level of a genuinely embraced value. The imbalance between the homogeneity of law school faculty and the diversity of law school students signals that while members of minorities may be capable of learning the law, they are unlikely to become sufficiently proficient to teach it. And further, homogeneity in the ranks of the professoriate suggests that assimilation is necessary for those who aspire to be acknowledged as proficient.

At the least, members of minorities have read such imbalances in this way, and some of them have conducted fierce and unflinching campaigns for increasing the proportion of law school professors who are women, members of racial minorities, or gay, lesbian, bisexual, or transgendered. ${ }^{1}$ There has been, however, very little similar activity to correct the imbalance of legal scholars with disabilities. In this Article, we consider whether there is reason to urge an increase in the number of individuals with disabilities, especially visible or otherwise evident disabilities, in the ranks of law school faculties.

\footnotetext{
* $\quad$ Leslie Pickering Francis (B.A., Wellesley College, 1967; Ph.D., University of Michigan, 1974; J.D., University of Utah, 1981) is Alfred C. Emery Professor of Law and Professor and Chair, Department of Philosophy, University of Utah. Anita Silvers (B.A., Sarah Lawrence College, 1962; Ph.D., Johns Hopkins University, 1967) is Professor and Chair, Department of Philosophy, San Francisco State University.

1. See, e.g., Charles R. Lawrence III, Two Views of the River: A Critique of the Liberal Defense of Affirmative Action, 101 Colum. L. REv. 928 (2001) (proposing a new defense of affirmative action based on a theory of transformative politics); Fox Butterfield, Harvard Law Professor Quits Until Black Woman Is Named, N.Y. Times, Apr. 24, 1990, at A1 (discussing a Harvard law professor's request for an unpaid leave of absence until Harvard appointed a tenured black woman to the law faculty).
} 


\section{Seeking Professors "Like Me"}

Many law schools have recognized that maintaining a homogenous faculty may impede efforts to diversify their students and in the long run reduce the inclusiveness of the legal profession. Suppose a young, aspiring, academically gifted African-American woman is contemplating applying to law school. She is thinking about pursuing a scholarly career and is drawn toward a future in which she breaks new ground interpreting, and teaching her interpretations of, the law.

Mindful of the importance of a welcoming climate, she needs to learn how people like her are perceived and received at law schools. She may wonder: Are there diverse student bodies? More important, are there diverse faculties, including people like her-i.e., recognition that people like her can be the leaders and teachers that shape her future profession?

The prospective law student is interested in seeing what role models she might find at various law schools. So, like many sensible students today, she "Googles" and visits law schools' websites. What information will she find? Does she find images of success for people like herself? Does she find photographs of people like herself being recognized for the products of their research? Or do the images she sees belong to groups of people that patently do not include her?

A Google search for "law professor" and "African American" would turn up, among the first several hits, reports of firsts achieved by African-American law professors: Lani Guinier's achievement of tenure at Harvard Law School ${ }^{2}$ and Tracey Meares's movement from the University of Chicago to Yale Law School. ${ }^{3}$ Among the first few hits would also be a description of Patricia Williams' distinguished career at Columbia Law School. ${ }^{4}$

If she visits the web pages of the top ten law schools, she would find similar welcoming images. With one exception, the websites of all highly ranked law schools contain photographs of people of color smiling happily and mingling with other students. ${ }^{5}$ The exception-Columbia Law

2. C. Stone Brown, Lani Guinier: Harvard's First Tenured Black Female Law Professor Continues to Make Her Voice Heard, NEw CRISIS, Mar.-Apr. 2001, available at http://findarticles.com/ p/articles/mi_qa3812/is_200103/ai_n8930678.

3. Spencer Overton, First African-American Woman to Join YLS Faculty, http://www.blackprof .com/archives/2006/05/tracey_meares_joins_yale_law_s.html (last visited Aug. 15, 2008).

4. See Wikipedia, List of African American Jurists, http://en.wikipedia.org/wiki/List_of_African_ American_jurists (last visited Aug. 15, 2008).

5. See, e.g., Yale Law School, Academics, http://www.law.yale.edu/academics/academics.htm(last 
School - has no photographs at all and instead has images of the majesty of the law. ${ }^{6}$

Now suppose a similarly aspiring student with a disability performs the same inquiry. What would she find with a Google search for "law professor" and "disability"? If she goes to the websites of major law schools, she would not find a single picture of a law student with visible disabilities. Instead, she would find photographs of students standing together, frolicking on the green, ${ }^{7}$ playing soccer, ${ }^{8}$ or competing in student Olympics. ${ }^{9}$ To be sure, under links for "students," she would find guidance for students with disabilities — about how the law schools provide reasonable accommodations for qualified students, and about how student services (located elsewhere on campus) are available should they wish to seek aid..$^{10}$

Would she also find people like herself pictured or otherwise represented in the publications law schools put out about their faculties? She would find reports of people involved in disability law by teaching or representing people in clinic work. ${ }^{11}$ But there would be almost no sign of people who are themselves disabled teaching in law schools. Even law professors with known disabilities would be portrayed with a standard head shot - a portrayal that may mask such conditions as dwarfism or paralysis. ${ }^{12}$

visited Aug. 15, 2008); Harvard Law School, JD Admissions, https://www.law.harvard.edu/admissions/jd/ (last visited Aug. 15, 2008); UCLA Law, Admissions Information, http://www.law.ucla.edu/home/ index.asp?page=791 (last visited Aug. 15, 2008); Michigan School of Law, Black Law Students Alliance, http://students.law.umich.edu/blsa/index.html (last visited Aug. 15, 2008); Stanford Law School, Student Life, http://www.law.stanford.edu/experience/studentlife (last visited Aug. 15, 2008); University of Virginia School of Law, Student Life, http://www.law.virginia.edu/html/students/students.htm (last visited Aug. 15, 2008); Duke University School of Law, Admissions, http://www.law.duke.edu/admis/apply/index (last visited Aug. 15, 2008); New York University School of Law, NYU Law Experience, http://experience.law.nyu.edu (last visited Aug. 15, 2008); The University of Texas at Austin School of Law, About The Law School, http://www.utexas.edu/law/depts/admissions (last visited Aug. 15, 2008).

6. Columbia Law School, http://www.law.columbia.edu/ (last visited Aug. 15, 2008).

7. See, e.g., The University of Michigan Law School, http://www.law.umich.edu (last visited Aug. 15, 2008).

8. See, e.g., Harvard Law School, Student Organizations: Soccer Club, http://www.law.harvard .edu/students/orgs/soccer/ (last visited Aug. 15, 2008)

9. See, e.g., The University of Texas at Austin School of Law, About The Law School, Photo Gallery, http://www.utexas.edu/law/about/photogallery/index.php?image_number=8 (last visited Aug. 15, 2008).

10. See, e.g., Yale Law School, Students with Disabilities, http://www.law.yale.edu/studentlife/ StudentswithDisabilities.asp (last visited Aug. 15, 2008); Harvard Law School, Disability Accommodations, http://www.law.harvard.edu/students/disability.php (last visited Aug. 15, 2008).

11. UNM Today, UNM Professor to be Honored for Work on Behalf of the Mentally Disabled, http://www.unm.edu/ market/cgi-bin/archives/002176.html (last visited Aug. 15, 2008).

12. See, e.g., University of Washington School of Law, Profile of Paul Steven Miller, 


\section{Data About Hiring Law School Faculty with Disabilities}

It does not appear that law schools indicate with any frequency an interest in hiring faculty members with disabilities. In the current "sample" listing of job vacancies, available on the Association of American Law Schools (AALS) web site, job applicants will find a brochure listing ninety-six schools with entry-level positions. ${ }^{13}$ Of the ninety-six, eighty-one schools list at least "diversity," or furtherance of equal employment opportunity guidelines, as an important hiring consideration. ${ }^{14}$ Of these, forty-eight specifically list "race" as a desirable diversity characteristic. ${ }^{15}$ Interestingly enough, after Grutter $v$. Bollinger,${ }^{16}$ twenty-three of these are state-funded law schools. ${ }^{17}$

Ten schools have job listings that mention disability among desired diversity characteristics. ${ }^{18}$ These are: Alabama, Drexel, George Mason, Loyola-Los Angeles, Minnesota, Pace, Santa Clara, Seattle University, Tulsa, and Utah. ${ }^{19}$ But two of these (Minnesota and Santa Clara) are schools listing two jobs each, one for a regular tenure-track position and the other for a clinic position; the reference to disability will be found in the clinical but not the tenure-track position, ${ }^{20}$ perhaps because clinical faculty often supervise students in what might be regarded as civil-rights activist areas. Of the ten schools, four are public universities and four are schools with traditional religious affiliations. ${ }^{21}$ Of these, the highest-ranked school is The University of Minnesota, ranked 20th in the latest U.S. News \& World Report Graduate School Rankings. ${ }^{22}$ George Mason University, the first school mentioning disability as a diversity characteristic for faculty members, is ranked 34th. ${ }^{23}$ The University of Alabama ranks 36th; The University of Utah ranks 57th;

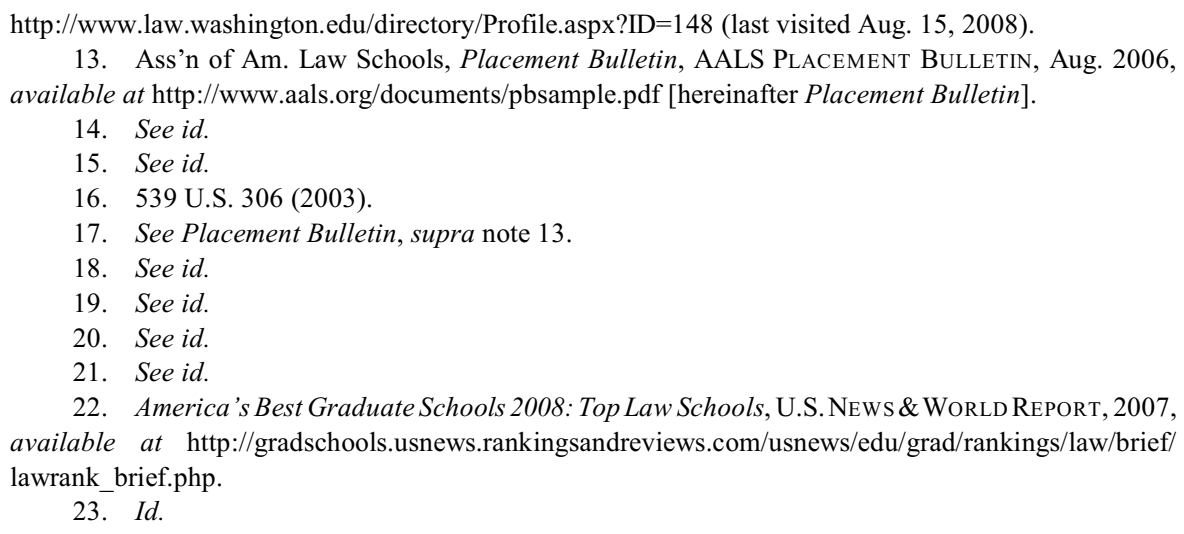


Loyola Law School 66th; Seattle University 85th; Santa Clara University 91 st; and the remainder do not rank in the top $100 .{ }^{24}$

At present, the AALS does not collect data about people with disabilities in law schools - either teachers or students. To some extent, this would be difficult to do because the availability of statistics of this kind rely on the willingness of individuals to disclose their disability status. Notably, some disabilities are manifest - mobility impairment, blindness, or severe burns, for example. But others, such as deafness, seizure disorders, or schizophrenia, ${ }^{25}$ can remain hidden. There may be disadvantages to disclosure, so people may never disclose or disclose only after they believe it is safe to do so, perhaps after they receive tenure or otherwise find themselves esteemed by colleagues.

Nor does the AALS currently provide a direct way through which disclosure of disability status could be taken into account in the law-faculty application process. Every year, the AALS mounts an elaborate placement service process through which law schools list available positions, job candidates register and submit resumes, and interviews are conducted at a conference in Washington, D.C. Although the job-applicant registration form contains a blank space in which the applicant can self-identify her race and ethnicity, no such space exists for an applicant to self-identify any disabilities. One of the authors of this Article attended the October, 2007, job placement conference as an interviewer. At all the various receptions for interviewers and candidates, and during various times in the hotel common areas, she observed only one person, a job candidate, with a visible disability — wheelchair use. These observations are admittedly anecdotal but possibly indicative of the fact that neither the interviewers nor interviewees included a significant number of people with visible disabilities.

It is not clear how good an idea it would be for this listing to be included. On the one hand, it signals that information about disability is salient and valued. On the other hand, the blank space is unlikely to be filled in very often. Applicants for law-teaching positions may quite appropriately fear that disclosure of a disability would hamper them in the job market and choose not

24. Id.

25. See the blog of Elyn Saks, professor and associate dean at USC Law School, describing her battles with schizophrenia and her decision ultimately to disclose her condition at http://mylaw.usc.edu/ blog/index.cfm. See also Terri Cheney, Take Me As I Am, Whoever I Am, N.Y. TimES, Jan. 13, 2008, in which she describes how she "sailed through law school and quickly found career success as an entertainment lawyer" despite being bipolar. She notes, however, that "[o]ther than doctors, nobody knew. At work, where my skills and productivity were all that mattered, I could hide my secret with relative ease." Id. 
to disclose. ${ }^{26}$ Without the blank space, job applicants are not encouraged to make disclosures that may prove harmful to them; yet, critics might argue, a judgment to omit the space because people might reveal disadvantaging information is paternalistic at best.

\section{Self-identifying as Disabled}

Identifying one's self as having a disability renders that person vulnerable to disability discrimination. Nonetheless, there is a reason why doing so is sufficiently important to possibly be worth this risk. A scene in the book The Center Cannot Hold, by University of Southern California Law School Professor and Associate Dean Elyn Saks, suggests one of the values achieved when disabilities are made visible. Saks, who became symptomatic of schizophrenia as a pre-adolescent, was hospitalized with this condition while a student at Yale Law School. Very few people associated with Yale knew about her diagnosis, and she did not self-identify as a person with schizophrenia until after receiving tenure. The USC website lists her as an expert on mental health issues and the law, but not as a person with schizophrenia. ${ }^{27}$

While she was in law school, and sometime after Saks had herself been hospitalized and placed in restraints, the following conversation occurred:

While I was preparing my Note, $\left[{ }^{28}\right]$ I spoke to one mental health professional then on the Yale faculty. "Wouldn't you agree that being restrained is incredibly degrading?" I asked. "Not to mention painful. And frightening."

The professor looked at me in a knowing way. "You don't really understand," he said kindly. "These people are different from you and me. It doesn't affect them the way it would affect us." If only he knew, I thought to myself. ${ }^{29}$

When individuals with disabilities are not identified as such, it is much easier for non-disabled people with whom they work to consider the disabled to not be fully human. Prudence advises people who live with disabilities to camouflage this aspect of themselves; as a result, non-disabled people cannot

26. For a discussion of the questionable benefits of disclosure and litigation for people with mental illness, see Jeffrey Swanson et al., Justice Disparities: Does the ADA Enforcement System Treat People With Psychiatric Disabilities Fairly?, 66 MD. L. Rev. 94 (2006).

27. USC Gould School of Law: Elyn Saks, http://law.usc.edu/contact/contactInfo.cfm?detailID=300 (last visited Aug. 15, 2008).

28. Elyn R. Saks, Note, The Use of Mechanical Restraints in Psychiatric Hospitals, 95 YALE L.J. 1836 (1986).

29. Elyn R. Saks, The Center Cannot Hold: My Journey Through Madness 212 (2007) 
observe disabled people as part of ordinary interactions of everyday life, and the idea that disabled people are not fully human flourishes. When law faculty, and consequently law students (who will become legislators, judges, public officials, prosecutors, etc.), never interact with peers known to have disabilities, it is much easier for them to suppose that people with disabilities are somehow not fully human and to mistakenly infer that people with disabilities do not need or deserve the equal protection due to peers.

In contrast, consider the students of Jacobus tenBroek, a founding member and president of the National Foundation of the Blind, and a nationally admired scholar of constitutional law. ${ }^{30}$ Dr. tenBroek was a full professor in two academic departments at the University of California, Berkeley (and the head of one of those departments). ${ }^{31}$ Despite publishing prominent articles in law reviews (as well as several well-recognized and reviewed books), he was never appointed to the university's law faculty. For many years, however, he taught the university's central pre-law course. ${ }^{32}$ The obituary of tenBroek, published by Michael Tigar in the California Law Review, describes how he inspired pre-law students, ${ }^{33}$ including two who subsequently became members of the California Supreme Court, three who subsequently became Appellate Justices, and many more who became legislators, government officials, and law professors. ${ }^{34}$ Tigar describes the benefits to pre-law students of the methods devised by tenBroek to organize discussion among students he could not see..$^{35}$ A decade after tenBroek died, one of the authors of this Article personally encountered tenBroek's lasting influence on his students while advocating on behalf of people with disabilities in California for better access to higher education. Across the political spectrum, she found that legislators and officials educated at U.C. Berkeley during tenBroek's tenure cited him as the reason they did not doubt either the public benefit or the justice of ensuring equal access to higher education for students with blindness or other disabilities.

30. Lou Ann Blake, Who Was Jacobus tenBroek?, The Braille Monitor, May 2006, available at http://www.nfb.org/Images/nfb/Publications/bm/bm06/bm0605/bm060503.htm.

31. Id.

32. Michael E. Tigar, Jacobus tenBroek: In Memoriam, 56 CAL. L. Rev. 573, 573 (1968).

33. Id.

34. Jacobus tenBroek: The Man Beyond The Movement, The Braille Monitor, Feb. 1993, available at $\mathrm{http} / / / \mathrm{www} . \mathrm{nfb}$. org/images/nfb/publications/bm/bm93/brlm9302.htm\#1 .

35. Tigar, supra note 32, at 573. 


\section{Recruiting Law Professors with Disabilities}

It is worth noting that hiring and other preferences based on disability have not been prohibited as categorically unconstitutional. Statutes giving preference to disabled veterans have been enacted after many U.S. wars. That legislatures may enact programs that give preference to the disabled is an explicit theme in Cleburne v. Cleburne Living Center, Inc. ${ }^{36}$ the pivotal case establishing the Supreme Court's approach to disability discrimination. Further, several landmark Supreme Court decisions delineate policies that support permitting focused recruitment in the effort to achieve diversity in higher education. Regents of the University of California v. Bakke $e^{37}$ affirms that diversity is a multi-factorial and compelling state interest, encompassing

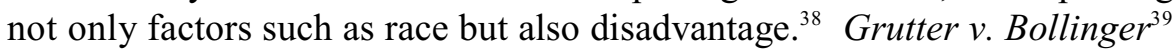
reminds us that "law schools cannot be effective in isolation from individuals and institutions with which the law interacts." 40 The national interests underlying affirmative recruitment and admission of law students articulated in Grutter apply to people with disabilities as well as racial minorities.

First, engaging with a diverse student body helps break down stereotypes that could impede fair application of principles of justice. In Grutter, the Court emphasized the importance of classroom discussion in this process. ${ }^{41}$ Take, for example, the stereotype that associates incompetence and inadequacy with disability; imagine how much more effectively that stereotype is shattered if students are proctored in classroom discussion by an individual with a disability - someone whom the students view as a superior rather than just a peer. Second, this kind of exposure complies with the importance Grutter assigns to preparing students for a diverse workforce. ${ }^{42}$

Third, Grutter simply asserts that exposure to a diverse student body is needed for a fair judiciary. ${ }^{43}$ Many cases of disability discrimination turn on whether people with disabilities should have access to sites, services, positions, or institutions that have previously excluded them, including

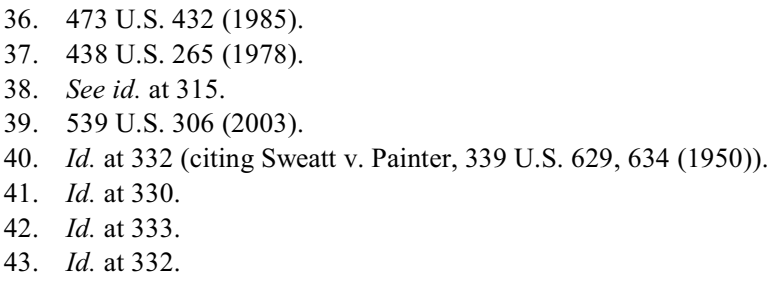


courthouses themselves. ${ }^{44}$ Being taught by professors with disabilities teaches future jurists that the disabled can flourish if only they have access.

Fourth, Grutter suggests that "the path to leadership be visibly open to talented and qualified individuals" of all types. ${ }^{45}$ There is no evidence that innate talent for the law or legal scholarship is less present among people with disabilities than in other minority groups. That people can become professors despite their disabilities is both a testimony to, and a reminder of, an institution's dedication to providing opportunities for talent.

\section{From the Standpoint of Disability}

Fifth, Grutter proposes that diversity among the professional colleagues with whom we interact enhances understanding. ${ }^{46}$ This idea aligns with what is known in epistemology as "standpoint theory." ${ }^{47}$ Standpoint theory asserts that the perspectives of marginalized individuals strengthen objectivity. ${ }^{48}$ Some standpoint theorists argue that oppressed people have privileged epistemological access to aspects of reality dominant people can't know, especially the realities of social relations. ${ }^{49}$ One reason given for the importance of recognizing and learning from the standpoint of marginalized people is that, unlike individuals whom current social organization accommodates comfortably, those who are at the periphery are not vested in veiling oppressive structures and relationships. ${ }^{50}$

An example of the perspectives that standpoint theory values is Patricia Collins's account of black women's experiences, which takes caring and responsibility as central to life's themes and assigns epistemic privilege to their descriptions. ${ }^{51}$ That is, how they speak about themselves overrides the standardized account imposed by those who dominate society. Similarly, standpoint theory offers disabled people epistemic privilege with regard to how they see their own lives.

\footnotetext{
44. See Tennessee v. Lane, 541 U.S. 509 (2004).

45. Grutter, 539 U.S. at 332.

46. Id. at 330

47. See, e.g., Heidi Grasswick, Feminist Social Epistemology, Stan. Encyclopedia of Phil., Nov. 9, 2006, available at http://plato.stanford.edu/entries/feminist-social-epistemology.

48. $I d$.

49. $I d$.

50. Id.

51. Patricia Hill Collins, Black Feminist Thought: Knowledge, Conscientiousness, and the Politics of Empowerment (2d ed. 2000).
} 
For example, people with disabilities are perhaps uniquely situated to understand what types of freedom are necessary to maintain liberty despite their disabilities. To illustrate, tenBroek wrote important amicus briefs and published influential scholarly work critiquing how welfare systems curtail people's liberty as the price exacted for providing them with basic support. His article, California's Dual System of Family Law: Its Origin, Development and Present Status, Parts $\mathrm{I}^{52}{ }^{\mathrm{II}},{ }^{53}$ and $\mathrm{III},{ }^{54}$ argues that statutes and jurisprudence in that state treat family matters differently for people of varying wealth, curtailing the freedoms of the poor as a price for welfare aid. The Disabled and the Law of Welfare ${ }^{55}$ co-authored with Floyd W. Matson, explores the conflicting policies of "custodialism" (confining people with disabilities to protect them) and "integrationism" (giving people with disabilities the right to participate with everyone else in the civic and commercial activities of the world). The forcefulness of his insights about what constitutes liberty for people with disabilities - being free to participate in civic and commercial activities, and especially to work - are evident in a profile of him in the New Yorker. ${ }^{56}$ His insights are explicated in his wellknown civil-rights article The Right to Live in the World: The Disabled and the Law of Torts. ${ }^{57}$

No individual with a disability engaged in constitutional law research today exercises the broad influence that tenBroek achieved. Whether anyone could do today what tenBroek did a half-century ago-building a national reputation for outstanding legal scholarship while lacking the status conferred by appointment to a law school faculty - is questionable. Today's educational practice gives scholars and teachers with disabilities who are not law school professors little access to law students and the legal profession. Law students do not have much opportunity to study and interact with teachers from venues inside the university but outside the law school. Thus, the absence of strong, visible participation (as peers) by scholars with disabilities on law school faculties, and the apparently prevailing disregard of disability in programs to diversify law school faculties, both narrow and weaken legal education.

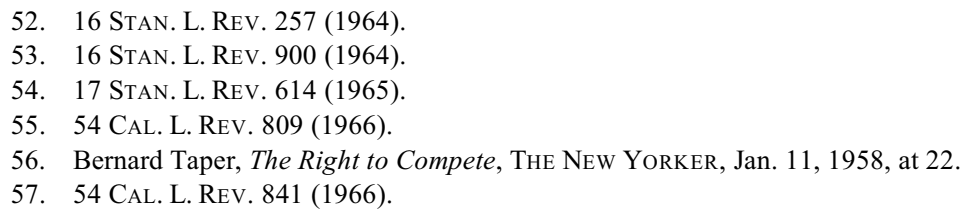

